\title{
Erratum to: CAR T Cell Therapy for Hematological Malignancies
}

Xin YANG, Gao-xiang WANG, Jian-feng ZHOU

Department of Hematology, Tongji Hospital, Tongji Medical College, Huazhong University of Science and Technology, Wuhan 430030, China

(C) The Author(s) 2021

\author{
Current Medical Science \\ https://link.springer.com/article/s11596-019-2118-z \\ 39(6):874-883,2019
}

The article "CAR T Cell Therapy for Hematological Malignancies", written by Xin YANG, Gao-xiang WANG, Jian-feng ZHOU, was originally published electronically on the publisher's internet portal on December 2019 without open access. With the author(s)' decision to opt for Open Choice, the copyright of the article is changed to (C) The Author(s) 2021 and the article is forthwith distributed under a Creative Commons Attribution 4.0 International License (https://creativecommons.org/licenses/ by/4.0/), which permits use, sharing, adaptation, distribution and reproduction in any medium or format, as long as you give appropriate credit to the original author(s) and the source, provide a link to the Creative Commons license, and indicate if changes were made.

The original article has been corrected.

Corresponding author: Jian-feng ZHOU 